\title{
Naberezhnye Chelny - implementation roadmap of the Master Plan-2022
}

\author{
Alexander Dembich ${ }^{10000-0001-8078-309 x]}$, Gulnara Mutallapova ${ }^{1}$, and Adelya Sayfutdinova ${ }^{*}{ }^{*}[0000-0003-4283-9712]$ \\ ${ }^{1}$ Kazan State University of Architecture and Engineering,420043 Kazan, Russia
}

\begin{abstract}
Currently, there is an actual issue of the low efficiency of the solutions implementation laid down in the urban planning documentation of the settlements master plan. This article discusses the key reasons that lead to such low implementation rates. Using the example of the developed Master Plan of the city of Naberezhnye Chelny for 2023-2037, the authors consider the roadmap not only as a key tool for increasing the efficiency of the implementation of urban planning documentation, but also as a way of correlating these solutions with the three-year planning cycle adopted in the legislation of the Russian Federation. The results of the study are the justified stages of the solutions implementation of the developed master plan with the points of growth of the city defined for each period.
\end{abstract}

Keywords. Master plan, implementation roadmap, urban planning documentation, strategic planning, points of growth, Naberezhnye Chelny.

\section{Introduction}

Today, in Russia as a whole, including in Tatarstan, there is a problem of a low level of implementation of the developed and approved design of urban planning settlements and territorial planning projects. If in the Soviet period this level after the expiration of these documents was from 40 to 70 percent, today, according to various experts, this level is only $7-15 \%$. It should be understood that the complexity of the preparation and the cost of such documents is quite high - the development of a master plan for a settlement, even a relatively small one, takes from 2 to 4 years, and the teams of performers of these works usually number several dozen people. For example, the master plan of the city of Kazan in 2007 lasted from 2003 to 2007, and the cost of the work was about 50 million rubles. The master plan of the city of Naberezhnye Chelny, being developed at the Kazan State University of Architecture and Engineering, currently costs 22 million rubles, and the duration of the work is determined from 2019 to 2022.

Considering that there are more than 2 thousand cities and about 150 thousand rural settlements in the Russian Federation today, this problem is acquiring a rather important economic significance.

There are three main reasons for the low level of implementation of urban planning documentation:

1. The lack of competent specialists-urban planners in the system of municipal government.

${ }^{*}$ Corresponding author: adelyasaif@rambler.ru 
The lack of such specialists has the following consequences - even in the presence of developed and approved urban planning documentation, construction processes on the territory unfold according to different scenarios. This is due to the fact that, without such specialists, few people are able to understand these urban planning documents, since the graphic and textual language of these documents is quite specific.

2. The lack of mandatory expertise of urban planning documentation, which means that it is «optional» to involve certified specialists in the development of urban planning documentation.

The lack of expertise also plays a significant role in the poor feasibility of urban planning documentation. According to the current urban planning code, the decision on the examination is made by the customer. And since such an examination is not cheap and requires a lot of time, it is much easier for the customer to refuse it altogether. Furthermore, this additionally «unties the hands» of the customer in case of various unforeseen deviations. The lack of expertise also contributes to the introduction of various types of amateurs into this process, in this type of activity, which also often leads to a noticeable decrease in the level of quality of urban planning documentation.

3. The absence in the urban planning documentations themselves of a clear investment substantiated plan for the stage-by-stage development of the territory - what is commonly called a «road map».

Roadmap (action plan) - a graphic display of the master plan with the designation of the main stages, key goals and deadlines, the main document for the implementation of the strategy.

If the first two reasons can be solved at the level of municipal management by administrative methods, then the issue of preparing a roadmap for the implementation of design urban planning documentation is an innovative moment, to a large extent a measure of the readiness and professional responsibility of the designers themselves [1-4].

At present, the design team of the Research and Design Center «Interra» of KSUAE, having concluded a municipal contract with the administration of the city of Naberezhnye Chelny, is developing a master plan for this urban district and, largely on its own initiative, includes a roadmap in the list of sections of this project.

When designing the Master Plan of Naberezhnye Chelny and the roadmap for its implementation, it is necessary to take into account not only the problems associated with the fact that at the present stage the city has become the center of the Kama agglomeration $[5,6]$, but also the effective use of landscape and ecological resources [7-10], transport policy and global trends in sustainable urban design [11-17]. In addition, the city is characterized by the typical problems of post-Soviet cities $[19,20]$. The use of modern approaches to territorial $[21,22]$ and strategic planning of cities will improve the quality of solutions made in the Master Plan [23].

The purpose of this study is to determine the main stages of the master plan implementation and key development points for drawing up a roadmap for the implementation of the master plan for the city of Naberezhnye Chelny.

To achieve this goal, it is necessary to solve the following tasks:

- to study and analyze the normative, legislative and other sources of information that determine the development of the city;

- to analyze the existing design practice in the city of Naberezhnye Chelny over the previous five years;

- to develop the stages of implementation of the master plan solutions, correlating with the strategic documents of urban development;

- to determine the points of growth of the planning districts of the city;

- to develop a system of priority measures for the formation of key facilities in each planning area of the city. 


\section{Materials and methods}

\subsection{Research methods}

To solve the set tasks, the generally accepted scientific research methods based on the analysis of the chronology of urban development in relation to socio-economic processes were used.

Research on theoretical sources includes:

- study, analysis and comparison of these strategies and programs for the socio-economic development of territories, with the identification of key priorities and the sequence of implementation;

- analysis of the sectoral programs of municipalities, since the municipal program is a set of activities, interrelated in terms of objectives, timing and resources, aimed at achieving specific goals and solving problems in the field of socio-economic development of the urban district. The priority tasks for the solution of which municipal programs are adopted are determined in accordance with the forecasts of the socio-economic development of the Russian Federation, the region, the urban district, the Strategy and the program of socioeconomic development;

- analysis of the existing design practice and reporting documents for the previous five years, identification of the features and trends of the city's development;

- analysis of the existing design and regulatory urban planning documentation of the city of Naberezhnye Chelny to identify the features of the chronological development of the city, functional and planning features, problematic issues in the existing urban planning regulatory framework that regulates urban development;

- study of domestic and international experience in the development and implementation of solutions for the implementation of master plans of settlements.

\subsection{Initial data}

The city of Naberezhnye Chelny is divided into three administrative districts: Central, Avtozavodsky, Komsomolsky. According to the Master plan of the city of Naberezhnye Chelny in 2017, the generalized balance of the modern functional use of the city (as of 2015) is [24]:

- industrial, communal storage areas and engineering communications areas $-22.7 \%$;

- territories under surface water bodies $-12.5 \%$;

- residential area $-11 \%$;

- territories of transport infrastructure $-10.5 \%$;

- territories of collective gardens $-6.2 \%$;

- public and business zones $-3.9 \%$;

- recreational area $-3.5 \%$;

- special-purpose territories - $2 \%$;

- others $-27.7 \%$.

Key tasks and goals defined in the Strategy of Socio-Economic Development for the Period up to 2030 and approved by the Resolution of the Executive Committee of Naberezhnye Chelny (dated September 27, 2016 № 5667):

- The goal of developing the Strategy: «To rework the long-term master plan of the city transformation process (2015) into a full-fledged metropolis «Metropolis Naberezhnye Chelny-2030» - the center of the» new» economy, successfully competing for markets, capital, talents and attention, the center of the Kama economic zones.

Tasks:

1. Identification of problems and clarification of the image of the future.

2. Development of a program and action plan for the transition to a new state. 
3. Increasing the attractiveness of the city. Formation of a vision of the city's prospects among the population, business, investors.

The main attention of the Strategy was focused on the need to quickly form a system of training and retraining of engineering and technical personnel for the industrial zones of the city and the Kama agglomeration. First of all, the question was about the creation of a large technological (polytechnic) university, which could become not only a forge of personnel, but also a center for the formation and development of the creative engineering potential of the agglomeration.

In previous studies [25], the key problematic issues of the spatial development of the city of Naberezhnye Chelny were identified, which were divided into two groups. The first group includes aspects indicated by the master plan of the city of Naberezhnye Chelny in 1972:

- the lack of a rational polycentric organization of the system of public centers of the city;

- the problem of the dominant transport-oriented direction in the planning structure of the city;

- the problem of total homogeneity of the mass development of the residential area of the city.

The first group of problematic issues was predetermined by the situation of the late $60 \mathrm{~s}$, early 70s of the twentieth century, within which the project team, under the leadership of B.R. Rubanenko, placed in the conditions of extremely limited design terms, was forced to abandon the full-fledged linking of the already established settlement system in the allocated territory into a single urban-planning organism. It was decided to «move away» a few kilometers to the east, from the existing settlements and design a completely separate «new city».

Another circumstance of this situation was the «euphoria of the coming motorization» of the Soviet population that reigned in the country, caused by the construction of a car plant in Togliatti, the gradually expanding production of Moskvich cars and insufficient awareness of such problems in the cities of Western countries.

The problem of the total monotony of the living environment of the city, which arises when using a limited number of standard projects in vast territories, significantly faded against the background of the extreme shortage of individual apartments for each family in all cities of the USSR. Suffice it to say that by the beginning of the 60 s in the cities of the country the amount of housing stock per person was usually below $6 \mathrm{~m}^{2}$.

The second group denotes the problems caused by changes in urban planning policy due to the emergence of the real estate market and new trends in urban planning:

- the problem of correspondence between the mission and the status of Naberezhnye Chelny as the nucleus of the Kama agglomeration;

- the problem of reorganization of the main planning units of the residential zone of the city - inter-highway territories (enlarged microdistricts);

- the problem of connecting urban public spaces with the Kama River coast.

\section{Results and discussion}

Considering that, according to the contract, the master plan should be completed in 2022, then its estimated period covers the period until 2037. According to the roadmap, it is proposed to divide its «life cycle» into three stages:

- from 2023 to 2025 ;

- from 2026 to 2031 ;

- from 2032 to 2037.

The timing of these stages was not chosen by chance, they correspond to the three-year cycle of economic planning adopted in the Russian Federation and are provided for by Federal Law 172 - FZ, «On Strategic Planning in the Russian Federation».

The first three-year stage (2023-2025) involves the simultaneous implementation of the preparation of assignments and the development of the most relevant land planning projects, adjustments to the current Land Use and Development Rules, placement and the initial stage 
of integrated development of key areas and the reconstruction of individual important fragments of the built-up area.

Among the activities of the first stage, it should be noted:

1.1. Construction of a federal bypass road on the southeastern side of the city - moving the M7 highway outside the city limits. Today, a federal highway passes through Naberezhnye Chelny, along which up to 10,000 cars cross the city every day. The removal of this highway outside the city limits will significantly reduce the load from transit vehicles.

1.2. Construction of a highway of urban significance through the «Orlovskoye Pole» - a continuation of Moskovsky Avenue. At one time, the construction of Moskovsky Avenue was not completed, in fact, the city with a length of $23 \mathrm{~km}$ is served by one highway - Musa Dzhalil Avenue, which turns into Naberezhnochelninsky Avenue. The construction of a highway through the «Orlovskoye Pole» will relieve the existing main road of the city and increase transport accessibility.

1.3. The beginning of the development of multi-storey housing in the Orlovsky Pole area and the central fragments of the Eastern planning area. Now the city has a rather low supply of housing - about 23 square meters per person. The new master plan proposes to increase this figure to 30-33 square meters, which brings it closer to European standards. Orlovskoe Pole is the most suitable area of the city for starting the construction of large residential areas, since it is practically not built up and does not require additional costs for the demolition of existing buildings. In addition, there are existing residential buildings around and, therefore, the necessary engineering communications have been carried out.

Second stage:

2.1. Development of the planning area of Mezhdurech'e, new development of the territory of the Aerated Concrete Plant and surrounding areas. The cellular concrete plant is currently not functioning. The new Master Plan assumes the reorganization of the territory of this plant and the territory of Mezhdurech'e.

2.2. Construction of new tram lines in the Komsomolsk region. The construction of these tram lines has already been laid by the city administration and will be carried out in the near future.

2.3. Construction of the second transport hub. Naberezhnye Chelny is an important transit point on the federal highway. The city has one transport hub in the western part. Since Naberezhnye Chelny has a pronounced linear structure, one transport hub is not able to meet the needs of a modern city. For this, the new master plan provides for the construction of a second one in the opposite eastern part of the city.

3.1. Expansion of the territories of multi-apartment buildings in the far part of the Vostochny district and the reconstruction of the existing low-rise buildings. Since the city is surrounded by such «barriers» as a river on the north side and a large industrial zone on the south, the eastern part of the city is the most accessible resource for housing construction.

3.2. Development of the southeastern territory (transfer of Chelny-Broiler production) of the city to the west of the KAMAZ plant complex. Earlier in clause 3.1. it was noted that there are not many territory resources in the city for the construction of the necessary volumes of residential buildings. Chelny-Broiler is a modern and efficient enterprise, therefore, at the first stages of the implementation of the master plan, it is impossible to carry out its transfer. The sanitary protection zone of the enterprise is $1 \mathrm{~km}$. The relocation of production outside the city at the later stages of the implementation of the solutions adopted in the Master Plan will open up good prospects for the development of the vacated urban area.

The city of Naberezhnye Chelny, starting with the Master Plan of 1972, prepared by the staff of Central Research Institute of Experimental Design «Zhilishcha» under the leadership of Academician B.R. Rubanenko was originally conceived as a city with a linear planning structure. Therefore, all this time it grew along the Kama, and by now its length in this direction has exceeded $22 \mathrm{~km}$. At the same time, the width of the residential area is 3.5-4.5 km on average. Such a configuration of the urban area requires the organization of a polycentric system of the 
urban level of service - a system of centers of urban significance, relatively evenly located along the lengthy transport communications located parallel to the Kama River.

Although in the strategy of socio-economic development (2016) the city is divided into two planning districts - South-West (Old City) and North-East (New City), it is proposed to allocate four planning districts on the urban territory with clear natural borders formed by characteristic elements of natural or artificially created elements of the landscape and main transport communications. In this regard, the city of Naberezhnye Chelny is characterized by a property inherent in most cities of the Soviet Union - the boundaries of planning areas provided for by urban planning documentation almost always do not coincide with the boundaries of the existing administrative areas of the city, which were defined at one time by other characteristics. The most important task of the developed master plan is the formation, reconstruction and development of centers of planning areas, designed to form the backbone of the system of service centers for the population, capable of providing the necessary level of comfortable life for citizens and the associated population of the entire territory of the Kama agglomeration. Nowadays, this system has to be formed virtually anew, having taken an inventory of the composition of the existing service system, which has developed mainly over the past 20-25 years, as a result of rather spontaneous initiatives of private business. Today, this should be a planned, targeted corrective activity to select the facilities necessary for the city's life, precisely balanced in purpose and carefully coordinated with the development of transport infrastructure.

In this regard, the roadmap for the implementation of the master plan outlines a system of priority measures for the formation of key objects of each of the planned centers of the planning district using the mechanisms of private-municipal partnership.

\section{Conclusion}

As a result of the study, the main stages of implementation of the solutions proposed in the project documentation of the Master Plan-2022, correlating with the three-year planning cycle proposed in the Russian Federation, were identified. Also, favorable points for the development of planning districts of the city are highlighted: places of concentration of business and cultural functions. This is necessary for the involvement of underutilized territories in the life of the city and the disclosure of their potential, due to which it is possible to achieve polycentricity of the formed urban system.

Implementing these three steps will require addressing the following issues:

- at the first stage, it is necessary to ensure the level of competence of architectural and urban planning services, municipal management either by completing these services with professionally trained urban planners, or by organizing retraining of existing employees with their subsequent certification in accordance with the current federal professional standard «Urban Planner». At the same stage, it is important to determine the priority of the development and development of territories and prepare urban planning tasks for the development of projects for planning the territory and schemes for the development of engineering and communal infrastructure;

- at the second and third stages of development, the most important issue is «debugging» cooperation with business and building a municipal-private partnership.

It is proposed to change the system of preparation of local planning projects of the territory, as the main method of planned implementation of the Master Plan. Based on the experience of urban planning carried out in some developed countries with market economies, it is proposed to form a package of agreements with investors and developers who have construction intentions in relation to land plots included in the boundaries of planned territorial planning projects during the development of land planning projects. This 
will require solving the problem of the need to hold tenders for the right to develop land plots, but it will significantly improve the quality of the expected results.

Of course, the transition to such a system for preparing territorial planning projects will require, in turn, a more serious and detailed development of technical specifications for such projects and a special form of contracts between the municipal authorities and applicants for the development of the territory. But it is precisely this experience of foreign municipal practice that demonstrates very positive results in terms of the quality of the resulting architectural environment and its adaptability to the modern needs of society.

\section{References}

1. K. Vishnevskiy, O. Karasev, D. Meissner. Integrated roadmaps for strategic management and planning, Technological Forecasting and Social Change 110, 153-166 (2016). DOI: 10.1016/j.techfore.2015.10.020.

2. C. Hornsby, M. Ripa, C. Vassillo, S. Ulgiati. A roadmap towards integrated assessment and participatory strategies in support of decision-making processes. The case of urban waste management, Journal of Cleaner Production 142 (1), 157-172 (2017). DOI: 10.1016/j.jclepro.2016.06.189.

3. L. Labaka, P. Maraña, R. Giménez, J. Hernantes. Defining the roadmap towards city resilience, Technological Forecasting and Social Change 146, 281-296 (2019). DOI: 10.1016/j.techfore.2019.05.019.

4. L. Criqui. Infrastructure urbanism: Roadmaps for servicing unplanned urbanisation in emerging cities, Habitat International 47, 93-102 (2015). DOI: 10.1016/j.habitatint.2015.01.015.

5. O.M. Polyakova. The regional agglomeration cultural environment integration and development with the use of the territory improvement information technology, IOP Conference Series: Materials Science and Engineering 698 (2), 022009 (2019). DOI: 10.1088/1757-899X/698/2/022009.

6. H. Rahayu, R. Haigh, D. Amaratunga. Strategic challenges in development planning for Denpasar City and the coastal urban agglomeration of Sarbagita, Procedia Engineering 212, 1347-1354 (2018). DOI: 10.1016/j.proeng.2018.01.174.

7. L.M. Musina, M.U. Neucheva. Role of the state in solving the environmental problems of the industrial monoprofile cities, IOP Conference Series: Earth and Environmental Science 107 (1), 012132 (2018). DOI: 10.1088/1755-1315/107/1/012132.

8. A.M. Hersperger, M. Bürgi, W.G. Wende, S. Bacău, S.R. Grădinaru. Does landscape play a role in strategic spatial planning of European urban regions?, Landscape and Urban Planning 194, 103702 (2020). DOI: 10.1016/j.landurbplan.2019.103702.

9. Y. Li, J. Qiu, B. Zhao, M. Pavao-Zuckerman, A. Bruns, S. Qureshi, C. Zhang, Y. Li. Quantifying urban ecological governance: A suite of indices characterizes the ecological planning implications of rapid coastal urbanization, Ecological Indicators 72, 225-233 (2017). DOI: 10.1016/j.ecolind.2016.08.021.

10. J.A. Diehl, E. Sweeney, B. Wong, C.S. Sia, H.Y., M. Prabhudesai. Feeding cities: Singapore's approach to land use planning for urban agriculture, Global Food Security 26, 100377 (2020). DOI: 10.1016/j.gfs.2020.100377.

11. S. Joshi, A. Bailey, A. Datta. On the move? Exploring constraints to accessing urban mobility infrastructures, Transport Policy 102, 61-74 (2021). DOI: 10.1016/j.tranpol. 2020.11.005.

12. L.L. Peter, Y. Yang. Urban planning historical review of master plans and the way towards a sustainable city: Dar es Salaam, Tanzania, Frontiers of Architectural Research 8 (3), 359-377 (2019). DOI: 10.1016/j.foar.2019.01.008. 
13. M.A. J.Q. Franco, P. Pawar, X. Wu. Green building policies in cities: A comparative assessment and analysis, Energy and Buildings 231, 110561 (2021). DOI: 10.1016/ j.enbuild.2020.110561.

14. S.T. Ng, F.J. Xu, Y. Yang, M. Lu, J. Li. Necessities and challenges to strengthen the regional infrastructure resilience within city clusters, Procedia Engineering 212, 198-205 (2018). DOI: 10.1016/j.proeng.2018.01.026.

15. S.R. Grădinaru, A.M. Hersperger. Green infrastructure in strategic spatial plans: Evidence from European urban regions, Urban Forestry \& Urban Greening 40, 17-28 (2019). DOI: 10.1016/j.ufug.2018.04.018.

16. H.D. Musa, M.R. Yacob, A.M. Abdullah. Delphi exploration of subjective well-being indicators for strategic urban planning towards sustainable development in Malaysia, Journal of Urban Management 8 (1), 28-41 (2019). DOI: 10.1016/j.jum.2018.08.001.

17. E. Feleki, C. Vlachokostas, N. Moussiopoulos. Holistic methodological framework for the characterization of urban sustainability and strategic planning, Journal of Cleaner Production 243, 118432 (2020). DOI: 10.1016/j.jclepro.2019.118432.

18. A.M. Hersperger, S. Grădinaru, E. Oliveira, S. Pagliarin, G. Palka. Understanding strategic spatial planning to effectively guide development of urban regions, Cities 94, 96-105 (2019). DOI: 10.1016/j.cities.2019.05.032.

19. T. Carter. Neighbourhood Improvement: The Role of Housing and Housing Institutions, International Encyclopedia of Housing and Home, 67-72 (2012). DOI: 10.1016/B978-008-047163-1.00486-0.

20. M. Fuhrman. Spatial, social and economical dynamic of contemporary Warsaw - City profile, Cities 94, 286-295 (2019). DOI: 10.1016/j.cities.2019.05.012.

21. T. Alizadeh. Does planning matter in smart cities?, Editor(s): T. Alizadeh, Global Trends of Smart Cities 5, 127-162 (2021). DOI: 10.1016/B978-0-12-819886-5.00008-6.

22. J. Wu, Q. Guo, G. J.D. Hewings. Land regulating economy as a policy instrument in urban China, Cities 94, 225-234 (2019). DOI: 10.1016/j.cities.2019.06.009.

23. R.S. de Graaf, G.P.M.R. Dewulf. Applying the lessons of strategic urban planning learned in the developing world to the Netherlands: A case study of three industrial area development projects, Habitat International 34 (4), 471-477 (2010). DOI: 10.1016/ j.habitatint.2010.02.005.

24. Federal state territorial planning information system https://fgistp.economy.gov.ru/ (last accessed 2021/04/05).

25. Y. Zakirova, A. Dembich, M. Latipova. The concept of transforming Naberezhnye Chelny urban planning structure, IOP Conference series. Materials Science and Engineering 890, 012007 (2020). DOI: 10.1088/1757-899X/890/1/012007. 